\title{
Administrative Organizational Ethical Climate Based on Social Interactionism
}

\author{
Bing Yan Keling Zheng Aihong Yang
}

School of Humanities and Arts, Northeast Petroleum University, Daqing, China, 163318

\begin{abstract}
Ethical climate in administrative organizations as an important branch of ethical climate research deserves more attentions. And interactionism provides a useful analytical framework to it. From the perspective of interactionism, it refers to common experiences and cognitions of staffs based on their administrative duties, roles and moral expectations. Interaction between members and ethical climate are regarded as members' resocialization. It also is closely related to administrative structure and process which pre-sets an ethical goal. Even though administration organizations provide moral references to them, members will not lose themselves in it, because during the interaction, members are active and have a free will, which means that they will take administrative obligations on jobs and serve for the public interests, not merely for that of themselves or their organizations.
\end{abstract}

Keywords: Administrative Organizations; Organizational Ethical Climate; Interactionism;

\section{Introduction}

Organizational ethical climate as an important component of organizational climate is put forward first by Murphy who believed it could influence a member's ethical behavior. Then Victor and others regards organizational ethical climate as members' common perception on what is ethical behavior and how to deal with eth- ical problems (Victor and Cullen, 1987). These opinions center on the individual and find dimensions of ethical climate, promoting the research of it. However, administrative organization ethical climate is seldom discussed from interactionism. Our study adopts the perspective of interactionism to explore the relationship between administrative organizational ethical climate and social interaction, as well as its influence on group membership and individual ethical behavior.

\section{Theoretical Background and Re- search Model Development}

Ethical climate in administrative organizations is a result of advancement of detail research. In order to understanding this item we should trace back to concepts: organizational ethical climate and administrative organization.

\subsection{Organizational ethical climate}

Generally speaking, climate refers to the general atmosphere or situation characterized in some stage of an organization. In 1935, Kurt Lewin, a famous social psychologist, discovered the rule of group dynamics in experiments about leadership mode and group psychological climate. He defined group climate as the common perception shared by individuals or cognitive patterns between them, and first put forward the concept psychological climate.

At the end of the 1970s, a lot of researchers began to study ethical climate 
in organizations and explore ethical factors of organizational climate, as well as relationship between ethical climate and organizational behavior. In 1987, Victor and Cullen brought forward the ethical climate and nine types of it. From then on, empirical research on dimensions and types matching of ethical climate took on a new look.

Nowadays, there are three perspectives to study organizational ethical climate: individuals, organization, and social interaction. The first perspective emphasizes individuals' role in forming ethical and psychological environment. The homogeneous relationship of members helps to produce the same perception. From the second perspective, features of organizational structure, such as centralization, specialization and professionalization, will make a special climate and bring pressure on members. It means same organizational situations make same perception. On the standpoint of Interactionism, interaction between people and surroundings is highlighted. Ethical climate is not structure, process or person, but the result that individuals try to understand their organization and their roles. It aims at exploring individuals' attitude, belief, motive, and behavior orientation which influence members' ethical behaviors, even the whole organization.

In addition, some details in organizational ethical climate are studied deeply, such as ethical climate's influences to organizational commitment, team innovation, organizational decision and human resources, as well as synergetic relationship between organizations and individuals. All of these laid a solid foundation for ethical climate in administrative organizations.

\subsection{Ethical climate in administrative organizations}

Administrative organizations as an essential part of public domain are greatly dif- ferent from private sphere. Public domain means a social public life world which relies on public management orders composed of fundamental social systems, justice arrangements and ordered structures. Administrative organizations are in charge of the public sphere. They could not merely advocate some professional ethical norms, as being loyalty and taking duties to organizations, but ought to be consistent with general social morality for general justice in our society. Ethical climate in administrative organizations is a moral state in which members can distinguish how to do is right in front of private, organizational and public interests, and supports them step out of moral dilemma.

- Ethical climate in administrative organizational is closely related to administrative structure and process and pre-sets an ethical goal.

When Weber's Bureaucracy theory is popular in the society, administrative organizations consist of hierarchy, strict selection systems and organizational structure, in which instrumental and obligation reason are emphasized. Then when getting a membership, administrative staffs ought to do their jobs in the boundary of law and regulations, and account for the government and public. Administrative staffs on behalf of public interests, not only work for themselves, but also serve citizens by increasing public welfare. That means whoever chooses to be a public servant is ready to dedicate themselves to it. In these case, public interests not private become the aim of administrative organization which pre-sets moral obligations for its staffs.

- Ethical climate in administrative organization refers to common experiences and cognitions of staffs based on their duties, roles and moral expectations.

In administrative organizations, value orientation consistently influences members and is enhanced by members' self 
and social evaluation. Based on this, ethical climate isn't merely to instill ideas. Furthermore, ethical climate can't manipulate members to do what is right and just. It can't completely resolve the ethical defects, but give members some moral advice. In some degree, it entitles members to make choice and to show their abilities on moral judgment and reflection.

- Ethical climate in administrative organization can be classified into positive climate and negative climate according to its influence to ethical behavior.

As every coin has two sides, ethical climate in administrational organizations brings about two effects. From a positive side, it helps to increase moral coherence of the organization. On the contrary, if moral values and standpoints are vague or wrong, it will lead to severe consequences. Under the group pressure, administrative staffs are afraid to express their opinions and obey demands of the organization in order to maintain their membership. Then when ideas partial to themselves or organizations occur, some behaviors deviating from social norms, such as concealing and nepotism, will be tacitly approved in administrative organizations. So what we should do is to balance: neither to make organizational climate a barrier to members' moral judgment, nor to make staffs abuse their administrative discretion.

\section{Interactionism and Administrative Organizational Ethical Climate}

From the perspective of interactionism, not only members' perceptions to ethical features, moral norms and obligations belong to ethical climate, but also involves interaction among members, ethical goal, and organizational structure are included. A group of scholars, such as Blake E. Ashforth (1985, p.837) believed some ideas of ethical climate were borrowed from interaction and socialization theory.

In some degree, interaction between members and ethical climate are looked on as members' resocialization. Before children grew up to an adult, the primary socialization was over and they have prepared for social life. But the socialization is never end, because people will learn new knowledge, accept new expectations and take new duties according to new reference group. The development of modern industrial society promotes the shift of reference group. In traditional agriculture society, living space and communicating sphere was so limited that people might get self-awareness and membership in blood relationship without much more imagination and creation. But it has changed greatly in industrial and globalized society. When people always change job, city and communication circles, the boundary of group is changed rapidly. They step into a society characterized by liquid modernity which is an uncontrollable living situation with more uncertainty, relativity and risks. People lost in the ontological anxiety and profession became an indispensable part of people's lives.

\subsection{Administration organizations providing moral reference for members}

Therefore, Administrative organization is not only a working place, but a place to cultivate intimate relationship and moral principles. During staffs complete duties and tasks in organization, they gradually know how to keep value neutrality and impartially use administrative authority. Resocialization reflects members' identification to professional situation.

Based on the identification to organization, staffs learn from other members how to deal with ethical problems and set up their principles of doing things. Nevertheless, when qualified people are chosen as administrative staffs at the beginning, 
they might not identify their roles and membership, and only work as demands of organization, just like a machine.

\subsection{Interaction between members and organization circumstances mak- ing staffs more active in ethical climate}

Based on interaction theory, administrative ethical climate begins at the classification of members. Staffs always draw psychological and physical boundaries of "we and they" which implies the ingroup and outgroup. Apparently, people working in the same department may be in a group. However this method totally neglects the psychological interaction and group identification of members. So job can't be a good criterion. More attention should be paid on the homogeny of members' perception, attitude and feelings to organizations. If staffs are classified simply, they will not share the moral cognition and advice, not to mention a healthy ethical climate. Now, many problems in administrative ethics are caused by lack of moral groups with clear ethical goals, boundaries and cohesiveness.

Relative to classification, members' identification to their membership is more important to form administrative ethical climate. Anyone in organizations is not isolated, but shares value and feelings with others. Gradually, they get a sense of belonging and membership. This is a dispersonality process. That is to say, they ought to change self-awareness from a single person to a member of an administrational organization. Then, they not only do their jobs, but also take duties and moral responsibilities which turn them into an indispensable part of a group. The matching of members' selfperception and ethical situation is very important to ethical climate. It is by the interaction among members that they complete identification to administrative organization. Once they acquire the membership, they can exclude some private profits and relationships to some extent, and reach a consensus to achieve public interests as real agents for the public.

In fact, membership of administrative organization can be shown only when compared with other groups. It will strengthen members' moral identification to their group and encourage them to positively evaluate administrative duties and tasks.

In conclusion, administrative ethical climate comes into being in the interaction between members and their organizations. On the basis of clear group boundaries, members obtain the ingroup ethical characteristics and membership which help them to acquire identification and superiority from organizations.

But attention should be paid is that once staffs highly identify the ethical goal of administrative organization, there will be a risk for ethical climate to neglect social moral norms and lead to ingroup moral ignoring public interests. Hence, the key is to balance two sides of interaction in administrative organizational ethical climate.

\section{References}

[1] B. Victor and B. Cullen, "Theory and measure of ethical climate in organizations," Research in Corporate Social Performance and Policy, pp. 5171, 1987.

[2] Fan-Chuan Tseng and Yen-Jung Fan, "Exploring the Influence of Organizational Ethical Climate on Knowledge Management," Journal of Business Ethics, pp. 325-342, 2011.

[3] Yau-De Wang and Hui-Hsien Hsieh, "Toward a Better Understanding of the Link between Ethical Climate and Job Satisfaction," Journal of Business Ethics, pp. 535-545, 2012. 